\title{
Bim and Noxa Are Candidates to Mediate the Deleterious Effect of the NF- $\kappa$ B Subunit RelA in Cerebral Ischemia
}

\author{
Ioana Inta, ${ }^{1}$ Stephan Paxian, ${ }^{2}$ Ira Maegele, ${ }^{1}$ Wen Zhang, ${ }^{1}$ Marina Pizzi, ${ }^{3}$ PierFranco Spano, ${ }^{3}$ Ilenia Sarnico, ${ }^{3}$ \\ Sajjad Muhammad, ${ }^{1}$ Oliver Herrmann, ${ }^{1}$ Dragos Inta, ${ }^{1}$ Bernd Baumann, ${ }^{4}$ Hsiou-Chi Liou, ${ }^{5}$ Roland M. Schmid, ${ }^{6}$ and \\ Markus Schwaninger ${ }^{1}$ \\ ${ }^{1}$ Department of Neurology, University of Heidelberg, 69120 Heidelberg, Germany, ${ }^{2}$ Molecular Neurology Unit, Department of Neurology, University of \\ Muenster, 48129 Muenster, Germany, ${ }^{3}$ Division of Pharmacology and Experimental Therapeutics, Department of Biomedical Sciences and Biotechnologies, \\ School of Medicine, University of Brescia, 25123 Brescia, Italy, ${ }^{4}$ Department of Physiological Chemistry, University of Ulm, 89081 Ulm, Germany, \\ ${ }^{5}$ Department of Medicine, Division of Immunology, Weill Medical College of Cornell University, New York, New York 10021, and ${ }^{6}$ Department of Internal \\ Medicine II, Technical University of Munich, 81675 Munich, Germany
}

The transcription factor nuclear factor $\kappa \mathrm{B}(\mathrm{NF}-\kappa \mathrm{B})$ is well known for its antiapoptotic action. However, in some disorders, such as cerebral ischemia, a proapoptotic function of NF- $\kappa$ B has been demonstrated. To analyze which subunit of NF- $\kappa$ B is functional in cerebral ischemia, we induced focal cerebral ischemia in mice with a germline deletion of the $p 52$ or $c$-Rel gene or with a conditional deletion of RelA in the brain. Only RelA deficiency reduced infarct size. Interestingly, expression of the proapoptotic BH3 (Bcl-2 homology domain 3)-only genes Bim and Noxa in cerebral ischemia depended on RelA and the upstream kinase IKK (I $\kappa$ B kinase). RelA stimulated Bim and Noxa gene transcription in primary cortical neurons and bound to the promoter of both genes. Thus, the deleterious function in cerebral ischemia is specific for the NF- $\kappa$ B subunit RelA and may be mediated through Bim and Noxa.

Key words: Bim; Noxa; cerebral ischemia; RelA; c-Rel; p52

\section{Introduction}

Members of the Bcl-2 family are sentinels of neuronal cell survival. Several studies have documented the role of Bcl-2 proteins in neuronal apoptosis after stroke (Graham et al., 2000; Cao et al., 2002). Bcl-2 proteins share four Bcl-2 homology domains, BH1 to BH4 (Strasser, 2005). Only a single BH3 domain is characteristic of a large subgroup of proapoptotic Bcl-2 family members, which includes Bim and Noxa. At the mitochondrial membrane, some $\mathrm{BH} 3$-only proteins directly activate the proapoptotic proteins Bax and Bak to release cytochrome $c$ and other death signals that trigger the caspase cascade. The antiapoptotic Bcl-2 and $\mathrm{Bcl}-\mathrm{X}_{\mathrm{L}}$ block Bax and Bak function. However, $\mathrm{BH} 3$-only proteins reverse this block and release Bak and Bax to trigger apoptosis. Thus, the ratio of proapoptotic and antiapoptotic Bcl-2 family members determines the fate of the cell.

Gene transcription regulates the ratio of proapoptotic and

Received Feb. 13, 2006; revised 0ct. 4, 2006; accepted 0ct. 4, 2006.

We thank Philippe Bouillet (The Walter and Eliza Hall Institute of Medical Research, Melbourne, Australia) for the Bim-luciferase construct and Tadatsugu Taniguchi (University of Tokyo, Tokyo, Japan) for the Noxa-luciferase construct. BMS-345541 was kindly provided by James Burke (Bristol-Myers Squibb, Princeton, NJ). We received a kind contribution of nestin-cre mice from Soizic Bourteele and Oliver Planz (Friedrich-Loeffler-Institute, Tübingen, Germany).

Correspondence should be addressed to Markus Schwaninger, Department of Neurology, University of Heidelberg, Im Neuenheimer Feld 400,69120 Heidelberg, Germany. E-mail: markus.schwaninger@med.uni-heidelberg.de.

I. Inta's present address: Department of Pediatrics, University of Heidelberg, 69120 Heidelberg, Germany.

W. Zhang's present address: Department of Surgery, Tongji Hospital, Tongji Medical College, Huazhong University of Science and Technology, Wuhan 430030, China.

DOI:10.1523/JNEUROSCI.3670-06.2006

Copyright $\odot 2006$ Society for Neuroscience $\quad 0270-6474 / 06 / 2612896-08 \$ 15.00 / 0$ antiapoptotic Bcl-2 family members. DNA damage induces apoptosis by stimulating expression of the BH3-only genes Noxa and Puma through p53 (Oda et al., 2000; Yu and Zhang, 2003). Bim is upregulated by the proapoptotic transcription factors FOXO and E2F1 and by c-Jun N-terminal protein kinase (JNK)/c-Jun signaling (Gilley et al., 2003; Kuan et al., 2003; Sunters et al., 2003; Hershko and Ginsberg, 2004). However, antiapoptotic family members are also regulated at the transcriptional level. The induction of $\mathrm{Bcl}-2$ and $\mathrm{Bcl}-\mathrm{X}_{\mathrm{L}}$ by the antiapoptotic transcription factor nuclear factor $\kappa \mathrm{B}$ (NF- $\kappa \mathrm{B}$ ) (Tamatani et al., 1999) is a well known phenomenon.

NF- $\kappa B$ consists of the five subunits p50, p52, RelA, c-Rel, and RelB. Surprisingly, in some paradigms, NF- $\kappa \mathrm{B}$ promotes apoptosis (Kaltschmidt et al., 2000, 2002; Pizzi et al., 2002). In a mouse model of stroke, NF- $\kappa \mathrm{B}$ was associated with neurodegeneration because germline deletion of the gene for the NF- $\kappa$ B subunit p50 reduced the infarct size (Schneider et al., 1999; Nurmi et al., 2004). Furthermore, expression of an NF- $\kappa$ B superrepressor was neuroprotective (Xu et al., 2002; Zhang et al., 2005), and inhibition or deletion of the upstream kinase I $\kappa$ B kinase (IKK) profoundly reduced the infarct size (Herrmann et al., 2005). The mechanisms that determine whether NF- $\kappa \mathrm{B}$ is proapoptotic or antiapoptotic are not known. Possibly, the five subunits exert distinct effects on cell survival. Indeed, functional diversity is suggested by the unique phenotypes of knock-out mouse lines ( $\mathrm{Li}$ and Verma, 2002). Recent evidence has shown that RelA exerts a proapoptotic and c-Rel an antiapoptotic effect in neurons (Pizzi et al., 2002, 2005). 
To investigate the function of NF- $\kappa \mathrm{B}$ subunits other than $\mathrm{p} 50$ in vivo, we induced cerebral ischemia in mice with a germline deficiency of p52 and c-Rel or with a conditional deletion of RelA in the brain. Deficiency of RelA but not of p52 or c-Rel reduced the infarct size. Moreover, RelA controlled the induction of the $\mathrm{BH} 3$-only genes Bim and Noxa in cerebral ischemia, providing a possible explanation for its deleterious effect. Our data suggest that, in addition to its known effect on antiapoptotic members, $\mathrm{NF}-\kappa \mathrm{B}$ may fine-tune cell survival by regulating the transcription of proapoptotic members of the Bcl-2 family.

\section{Materials and Methods}

Transgenic mice. RelA ${ }^{\text {flox/flox }}$ mice will be described elsewhere (R. M. Schmid, unpublished observations). LoxP sites were introduced between exons 6 and 7 and between exons 10 and 11 of the RelA gene. For controls, we used littermate RelA ${ }^{\text {flox/flox }}$ mice that were negative for the nestin-Cre balancer gene (Betz et al., 1996). After focal cerebral ischemia, nestin-Cre balancer mice and wild-type littermates had the same infarct size (data not shown). For Southern blot analysis, DNA isolated from the tails and various tissues of mice was digested with $B g l \mathrm{II}$ and separated in $1 \%$ agarose gels. For hybridization of DNA, a 431 bp genomic probe was used, and bands were detected by PhosphorImager (GE Healthcare, Little Chalfont, UK). c-Rel ${ }^{-1-}$ mice (Liou et al., 1999) were backcrossed for seven generations on a C57BL/6 background and $\mathrm{p}^{-1-}$ mice (Paxian et al., 2002) for $>10$ generations. Therefore, we used C57BL/6 mice as controls.

Cell culture. Cortical neurons were prepared from embryonic day 16 (E16) mice. For transfection, cells were plated on 24-well plates precoated with poly-D-lysine $(50 \mu \mathrm{g} / \mathrm{ml})$ at a density of 200,000 cells per well. For RNA preparation, 2,000,000 cells per well were plated on six-well plates. Cells were incubated in Neurobasal medium (Invitrogen, Karlsruhe, Germany) supplemented with B27 (Invitrogen), L-glutamine $(0.5 \mathrm{~mm})$, penicillin $(100 \mathrm{IU} / \mathrm{ml})$, and streptomycin $(100 \mu \mathrm{g} / \mathrm{ml})$. In these cultures, $>95 \%$ of cells were positive for the neuronal marker NeuN (neuronal-specific nuclear protein). Cells were used after $10 \mathrm{~d}$ in vitro.

Models of cerebral ischemia. As an in vivo model of permanent focal cerebral ischemia, a distal middle cerebral artery occlusion (MCAO) was performed. All mice were male and were anesthetized at the age of 3-4 months by intraperitoneal injection of $150 \mu \mathrm{l}$ of $2.5 \%$ Avertin (tribromoethanol) per $10 \mathrm{~g}$ of body weight. A skin incision was made between the ear and the orbit on the left side. The parotid gland and the temporal muscle were removed by electrical coagulation. The stem of the MCA was exposed through a burr hole and occluded by microbipolar coagulation (Erbe, Tübingen, Germany). Surgery was performed under a microscope (Hund, Wetzlar, Germany). A body temperature of $37^{\circ} \mathrm{C}$ was maintained in the mice by using a heating pad. After $48 \mathrm{~h}$, mice were deeply reanesthetized with Avertin and perfused intracardially with Ringer's solution.

The procedure for infarct measurement on cryosections and correction for cerebral edema has been described previously (Herrmann et al., 2003). In a separate cohort of animals, the femoral artery was cannulated to measure arterial blood gases and mean arterial blood pressure. Arterial blood gases, glucose, and hemoglobin were measured $15 \mathrm{~min}$ before and $15 \mathrm{~min}$ into MCAO in a blood sample of $100 \mu \mathrm{l}$. For laser Doppler measurements, the probe (P415-205; Perimed, Piscataway, NJ) was placed $3 \mathrm{~mm}$ lateral and $6 \mathrm{~mm}$ posterior to the bregma. Relative perfusion units were determined (Periflux 4001; Perimed).

Drugs were administered 10 min before MCAO. Vehicle ( $0.9 \%$ saline) or BMS-345541 solution (both $2 \mu \mathrm{l}$ ) was injected into the lateral ventricle, using a $10 \mu \mathrm{l}$ Hamilton syringe, $0.9 \mathrm{~mm}$ lateral, $0.1 \mathrm{~mm}$ posterior, and $3.1 \mathrm{~mm}$ deep relative to the bregma.

Oxygen glucose deprivation (OGD) was used as an in vitro model of ischemia. For OGD experiments, primary cortical neurons that had been in culture for $10 \mathrm{~d}$ were transferred into serum-free medium containing 5 mm 2-deoxy-D-glucose (Merck, Darmstadt, Germany) for $1 \mathrm{~h}$. Then, the cells were placed in an anaerobic chamber that was flushed for $10 \mathrm{~min}$ with a mix of $95 \% \mathrm{~N}_{2}$ and $5 \% \mathrm{CO}_{2}$. After incubation for the indicated times, cells were removed from the anaerobic chamber and incubated under normal conditions for another $24 \mathrm{~h}$. The control group was cul-

\section{Table 1. Primers used for real-time RT-PCR}

\begin{tabular}{|c|c|c|c|}
\hline Gene & Amplicon length (bp) & Sequence & $\mathrm{Tm}$ \\
\hline \multirow[t]{2}{*}{ Cyclophilin } & \multirow[t]{2}{*}{51} & 5'-AGGTCCTGGCATCTTGTCCAT-3' & $59.3^{\circ} \mathrm{C}$ \\
\hline & & 5'-GAACCGTTTGTGTTTGGTCCA-3' & $59.5^{\circ} \mathrm{C}$ \\
\hline \multirow[t]{2}{*}{ Bid } & \multirow[t]{2}{*}{57} & $5^{\prime}$-AGCCAGATTCGTAAAGTCAGGAA-3' & $57.4^{\circ} \mathrm{C}$ \\
\hline & & 5'-GGGCGAGATGTCTGGGAAT-3' & $59.2^{\circ} \mathrm{C}$ \\
\hline \multirow[t]{2}{*}{ Bik } & \multirow[t]{2}{*}{54} & 5'-CTCAGCTTGGCAGAACACATG-3' & $58.1^{\circ} \mathrm{C}$ \\
\hline & & 5'-GATGACGTCTCTGGCCATAAGTCT-3' & $58.7^{\circ} \mathrm{C}$ \\
\hline \multirow[t]{2}{*}{ Bim } & \multirow[t]{2}{*}{51} & 5'-ACAGAACCGCAAGCTTCCAT-3' & $59^{\circ} \mathrm{C}$ \\
\hline & & 5'-CAGATCTTCAGGTTCCTCCTGAGA-3' & $58.4^{\circ} \mathrm{C}$ \\
\hline \multirow[t]{2}{*}{ Bad } & \multirow[t]{2}{*}{51} & 5'-TCCGAAGGATGAGCGATGAG-3' & $58.2^{\circ} \mathrm{C}$ \\
\hline & & 5'-GGCGAGGAAGTCCCTTGAAG-3' & $59.8^{\circ} \mathrm{C}$ \\
\hline \multirow[t]{2}{*}{ Bnip3 } & \multirow[t]{2}{*}{55} & 5'-CTCATCTGCTGGCCATTGG-3' & $58.3^{\circ} \mathrm{C}$ \\
\hline & & 5'-GAAGTTGTCAGACGCCTTCCA-3' & $58.7^{\circ} \mathrm{C}$ \\
\hline \multirow[t]{2}{*}{ Hrk } & \multirow[t]{2}{*}{58} & $5^{\prime}-\mathrm{TCCCACACGCGCAACCTT-3^{ \prime }}$ & $60.7^{\circ} \mathrm{C}$ \\
\hline & & 5'-TGCCACCCTAGACATTACGAAGT-3' & $58.6^{\circ} \mathrm{C}$ \\
\hline \multirow[t]{2}{*}{ Noxa } & \multirow[t]{2}{*}{73} & $5^{\prime}$-CTGGGAAGTCGCAAAAGAGC-3' & $58.9^{\circ} \mathrm{C}$ \\
\hline & & 5'-CACTCGTCCTTCAAGTCTGCTG-3' & $58.8^{\circ} \mathrm{C}$ \\
\hline \multirow[t]{2}{*}{ Nix } & \multirow[t]{2}{*}{61} & $5^{\prime}$-TGACAGCCCTTCACCACAAG-3' & $58.7^{\circ} \mathrm{C}$ \\
\hline & & 5'-GCTGGTATGCATCTCAACATCAAA-3' & $58.3^{\circ} \mathrm{C}$ \\
\hline \multirow[t]{2}{*}{ Puma } & \multirow[t]{2}{*}{78} & $5^{\prime}$-AGCGGCGGAGACAAGAAGA-3' & $59.8^{\circ} \mathrm{C}$ \\
\hline & & 5'-GGAGTCCCATGAAGAGATTGTACA-3' & $56.7^{\circ} \mathrm{C}$ \\
\hline \multirow[t]{2}{*}{ Sipa1 } & \multirow[t]{2}{*}{102} & 5'-GTGGAATCCGTTTTGGTATCCA-3' & $58.5^{\circ} \mathrm{C}$ \\
\hline & & $5^{\prime}$-CGGAGCAGCCTTTATGCAGTT-3' & $60.7^{\circ} \mathrm{C}$ \\
\hline
\end{tabular}

Tm, Melting temperature.

tured in parallel but did not receive 2-deoxy-D-glucose and was not flushed with $\mathrm{N}_{2} / \mathrm{CO}_{2}$. Then, RNA was extracted.

$N F-\kappa B D N A$ binding assay. Mice were reanesthetized and perfused with Ringer's solution $4 \mathrm{~h}$ after MCAO. The ischemic core and periphery and contralateral cortices (each $18 \mathrm{~mm}^{2}$ ) were quickly dissected with a sample corer (Fine Science Tools, Foster City, CA). Nuclear fractions were isolated using commercially available reagents (Nuclear Extract Kit; Active Motif, Rixensart, Belgium). DNA binding activity of NF- $\kappa \mathrm{B}$ subunits p50, p65, c-Rel, p52, and RelB was monitored using a commercially available ELISA-based assay (TransFactor; BD Biosciences, Mountain View, CA) (Pizzi et al., 2005). Briefly, nuclear samples ( $3 \mu \mathrm{g}$ ) were incubated in an ELISA plate coated with oligonucleotides containing an NF- $\kappa$ B consensus regulatory element sequence. The wells were washed and exposed to a primary antibody specific for each subunit of NF- $\kappa \mathrm{B}$ p50, p65, and c-Rel included in the assay kit. To detect p52 and RelB, wells were exposed to anti-RelB antibody (1:200, sc-226X; Santa Cruz Biotechnology, Heidelberg, Germany) and to anti-p52 (1:200; sc-848X; Santa Cruz Biotechnology). Binding of the primary antibody to protein was detected through a chromogenic reaction involving the enzymatic breakdown of 3,3',5,5' -tetramethylbenzidine via a horseradish peroxidase (HRP)-conjugated secondary antibody. Reactions were quantified spectrophotometrically at a wavelength of $655 \mathrm{~nm}$. For each run, a series of positive and negative controls was performed to ensure the detection specificity of NF- $\kappa$ B DNA binding activity.

Immunoblots. Nuclear extracts (used for ELISA assay) or brain lysates from control and RelA ${ }^{\text {CNSKO }}$ mice were resolved by $10 \%$ or $15 \%$ SDSPAGE. Prestained molecular size markers were used as molecular mass standards. The gels were electroblotted onto Hybond ECL nitrocellulose membrane (GE Healthcare). Immunodetection of the protein of interest was performed with the following antibodies: c-Rel, RelA, RelB, p52, extracellular signal-regulated protein kinase 2 (Erk2; Santa Cruz Biotechnology), p50 (Abcam, Paris, France), Bim (Calbiochem, Schwalbach, Germany), phospho-IKK1 (Ser180)/IKK2 (Ser181; Cell Signaling Technology, Beverly, MA), and actin (Sigma, Taufkirchen, Germany). The membranes were then probed with HRP-conjugated secondary antibody. For detection, we used enhanced chemiluminescence (ECL; GE Healthcare). For RelA and p50 detection in brain lysates of RelA ${ }^{\text {CNSOO }}$ or control mice, the ECL Advance Western Blotting Detection Kit (GE Healthcare) was used. Quantitative analysis was performed with the NIH ImageJ program.

Real-time reverse transcription-PCR. Mice were reanesthetized and perfused with Ringer's solution at 6,15 , or $24 \mathrm{~h}$ after MCAO. The isch- 
emic and contralateral cortices were quickly dissected and frozen on dry ice. Tissues were stored at $-80^{\circ} \mathrm{C}$. RNA from cortex or cultured cells was extracted with peqGOLD RNAPure (PEQLAB, Erlangen, Germany), according to the manufacturer's instructions. RNA $(10 \mu \mathrm{g}$, cortex; $7.5 \mu \mathrm{g}$, cells) was transcribed with Moloney murine leukemia virus reverse transcriptase and random hexamers. Primers used for PCR amplification are described in Table 1.

PCR was performed according to the following protocol: $10 \mathrm{~min}$ at $95^{\circ} \mathrm{C}, 15 \mathrm{~s}$ at $95^{\circ} \mathrm{C}$, and 1 min at $60^{\circ} \mathrm{C}$ (40 cycles). Amplification was quantified with the Gene Amp 5700 sequence detector and the SYBR Green kit (PE Diagnostik, Weiterstadt, Germany). A linear concentration-amplification curve was established by diluting pooled samples. Quantified results for individual cDNAs were normalized to cyclophilin. With this procedure, we can quantify results relative to a control group. The purity of the amplified products was checked by the dissociation curve and gel electrophoresis of selected samples.

Immunohistochemistry and terminal deoxynucleotide transferase-mediated biotinylated UTP nick end labeling staining. For immunohistochemical detection of active RelA, neurofilament-200, Bim, and Noxa, permanent MCAO was performed in wild-type mice. Two hours and $24 \mathrm{~h}$ after MCAO, mice were reanesthetized and perfused with $4 \%$ paraformaldehyde (PFA). Brains were incubated overnight in $4 \%$ PFA and then embedded in paraffin. Sections $(1 \mu \mathrm{m})$ were incubated overnight at $4^{\circ} \mathrm{C}$ with the following antibodies: active RelA (Millipore, Billerica, MA), neurofilament-200 (Sigma), Bim (Stressgen Biotechnologies, Victoria, British Columbia, Canada), and Noxa (Imgenex, San Diego, CA). For detection, secondary fluorescein-linked anti-rabbit IgG antibody (Vector Laboratories, Burlingame, CA) and rhodamine-conjugated anti-mouse IgG antibody (Jackson ImmunoResearch Laboratories, West Grove, PA) were used. To exclude the possibility of false labeling, we omitted primary and secondary antibodies.

For terminal deoxynucleotide transferasemediated biotinylated UTP nick end labeling (TUNEL) staining, sections prestained with anti-Bim or anti-Noxa antibody were incubated with $50 \mu$ l of TUNEL reaction mix (In Situ Cell Detection Kit, TMR red; Roche Diagnostics, Mannheim, Germany) for $1 \mathrm{~h}$ at $42^{\circ} \mathrm{C}$. After washing three times, slides were mounted with medium containing $4^{\prime}, 6^{\prime}$-diamidino-2phenylindole dihydrochloride (DAPI; Vectashield; Vector Laboratories).

Site-specific mutation and transfection. The following plasmids have been described previously: Noxa-luciferase $(-183 /+146)$ (Oda et al., 2000) and Bim-luciferase $(-3600 /+96)$ (Bouillet et al., 2001). NF- $\kappa$ B binding sites were mutated in Noxa- and Bim-luciferase plasmids, using the QuikChange II Site-Directed Mutagenesis Kit (Stratagene, La Jolla, CA) as recommended. To generate Noxa-mutated binding sequence of the $\kappa \mathrm{B}$ promoter $(\mathrm{m} \kappa \mathrm{B})-$ luciferase and Bim-m $\mathrm{m} \mathrm{B}-$ luciferase plasmids, the following primers were used: CGT CAC ATG ACG TCA CCG AAG AAG TCA CGA TAA AAT GCG AGA GCC (Noxasize is noted in the boxes.
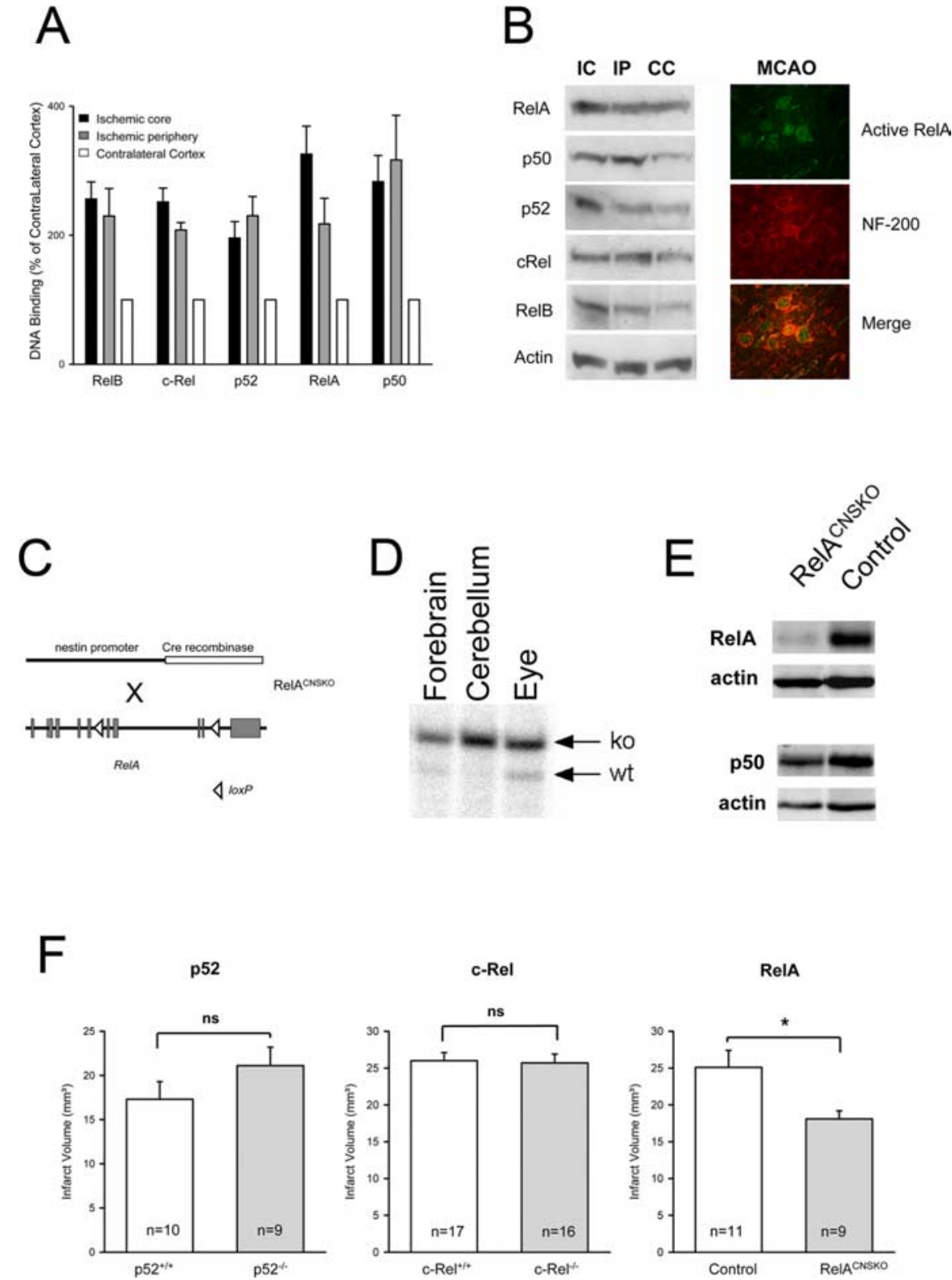

Figure 1. Activation and function of NF- $\kappa B$ subunits in cerebral ischemia. $A, A l l$ five subunits of NF- $\kappa B$ were activated after $4 \mathrm{~h}$ of MCAO. DNA binding in the ischemic and the corresponding contralateral cortex was measured with an ELISA-based assay. Values are means \pm SEM $(n=6)$ and expressed as a percentage of the respective contralateral control. Core and periphery were dissected according to a standardized protocol (see Materials and Methods). $\boldsymbol{B}$, Increased nuclear concentrations of the five subunits of NF- $\kappa B$ after cerebral ischemia. Immunoblots of nuclear extracts of the ischemic core (IC), ischemic periphery (IP), and the contralateral cortex $(\mathrm{CC})$ after $4 \mathrm{~h}$ of MCAO are shown (left). Nuclear translocation of active RelA (green) was detected in neurofilament-200-positive neurons (NF-200; red) $2 \mathrm{~h}$ after permanent MCAO by immunohistochemistry (right). $\boldsymbol{C}$, Genetic strategy to generate ReIA ${ }^{\text {CNSKO }}$ mice. The nestin-Cre balancer gene was introduced into mice that were homozygous for the floxed RelA allele. Exons of the RelA gene are depicted as gray boxes. D, RelA ${ }^{\text {CNSKO }}$ mice were mosaics for the deleted RelA gene in several organs. However, in cerebellum, forebrain, and eye, the mutated allele predominates, as shown by a Southern blot. ko, Knock-out; wt, wild type. $\boldsymbol{E}$, RelA protein concentration was significantly reduced in the noninfarcted hemisphere of RelA ${ }^{\mathrm{CNSKO}}$ mice compared with controls ( $p<0.05 ; n=13-15$; two-tailed $t$ test). Representative immunoblots are shown. $\boldsymbol{F}$, Conditional deletion of RelA in the brain reduced infarct volume, whereas deletion of $\mathrm{p} 52$ or c-Rel had no effect on the infarct size. The infarct volume was measured $48 \mathrm{~h}$ after permanent MCA0. ${ }^{*} p<0.05$ (two-tailed $t$ test). ns, Not significant. Values are means \pm SEM. The sample

mкB1), GCA GCC CGA GTC TTG GAA GAG CCC CAG AGC CCA GAT TGG (Noxa-m $\kappa$ B2), and GCC GTG GGG GGT AGG GCT TAT CTT CCG GCT TGC (Bim-mкB). Mutated plasmids were confirmed by sequencing.

After $10 \mathrm{~d}$ in vitro, cortical neurons were transfected using Lipo- 
Table 2. Physiological parameters $15 \mathrm{~min}$ before and $15 \mathrm{~min}$ after MCAO in RelA ${ }^{\mathrm{CNSKO}}$ mice and littermate controls

\begin{tabular}{|c|c|c|c|c|}
\hline \multirow[b]{2}{*}{ Parameter } & \multicolumn{2}{|l|}{$\operatorname{Rel} A^{\text {CNSKO }}$} & \multicolumn{2}{|l|}{ Controls } \\
\hline & Pre-MCAO & Post-MCA0 & Pre-MCAO & Post-MCAO \\
\hline MABP (mmHg) & $70.0 \pm 2.1$ & $61.4 \pm 3.3$ & $69.1 \pm 3.8$ & $61.6 \pm 3.1$ \\
\hline Heart rate (per min) & $433.3 \pm 9.1$ & $468.6 \pm 10.4$ & $403.4 \pm 9.7$ & $452.4 \pm 10.1$ \\
\hline Glucose (mg/dl) & $185.1 \pm 9.9$ & $224.5 \pm 17.0$ & $189.6 \pm 9.8$ & $245.3 \pm 21.2$ \\
\hline Arterial $\mathrm{pCO}_{2}(\mathrm{mmHg})$ & $63.0 \pm 1.8$ & $63.3 \pm 2.8$ & $67.5 \pm 5.6$ & $62.2 \pm 2.7$ \\
\hline Arterial $\mathrm{pO}_{2}(\mathrm{mmHg})$ & $76.7 \pm 2.3$ & $77.1 \pm 4.6$ & $83.3 \pm 6.0$ & $83.8 \pm 6.8$ \\
\hline $\mathrm{pH}$ & $7.15 \pm 0.02$ & $7.11 \pm 0.02$ & $7.17 \pm 0.03$ & $7.14 \pm 0.03$ \\
\hline Base excess & $-8.8 \pm 0.8$ & $-10.7 \pm 0.9$ & $-8.2 \pm 1.3$ & $-10.5 \pm 0.9$ \\
\hline $\mathrm{Hb}(\mathrm{g} / \mathrm{L})$ & $15.3 \pm 0.4$ & $13.1 \pm 0.3$ & $15.3 \pm 0.4$ & $13.4 \pm 0.4$ \\
\hline Laser Doppler (relative units) & $86.7 \pm 4.3$ & $14.0 \pm 0.7$ & $93.8 \pm 4.1$ & $11.5 \pm 1.6$ \\
\hline Body weight $(\mathrm{g})$ & $32 \pm 2$ & & $32 \pm 3$ & \\
\hline
\end{tabular}

None of the parameters differed significantly between the groups ( $t$ test). Values are means $\pm \mathrm{SEM} ; n=5-8$. MABP, Mean arterial blood pressure; $\mathrm{Hb}$ hemoglobin concentration.

A
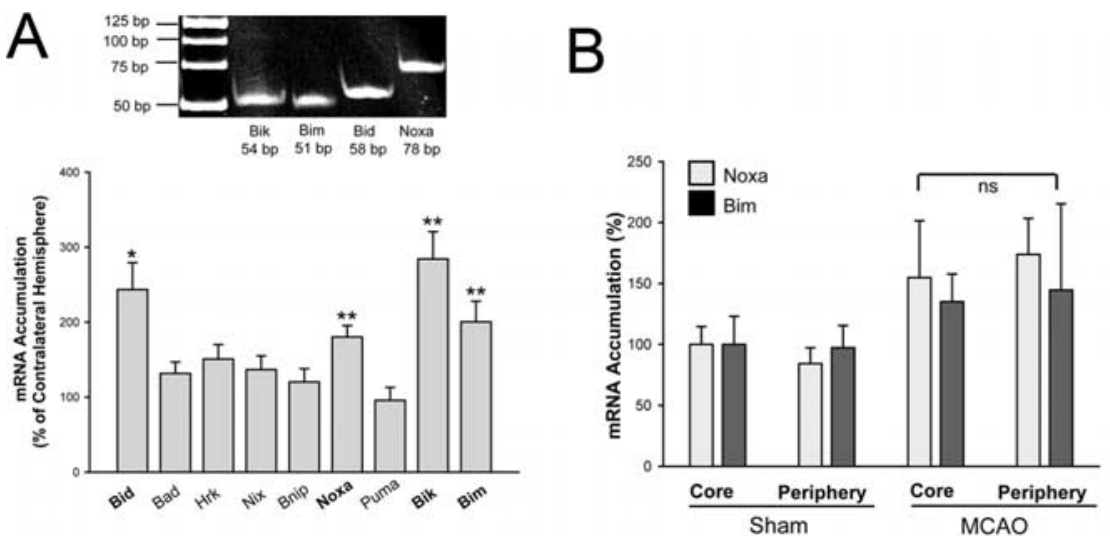

C

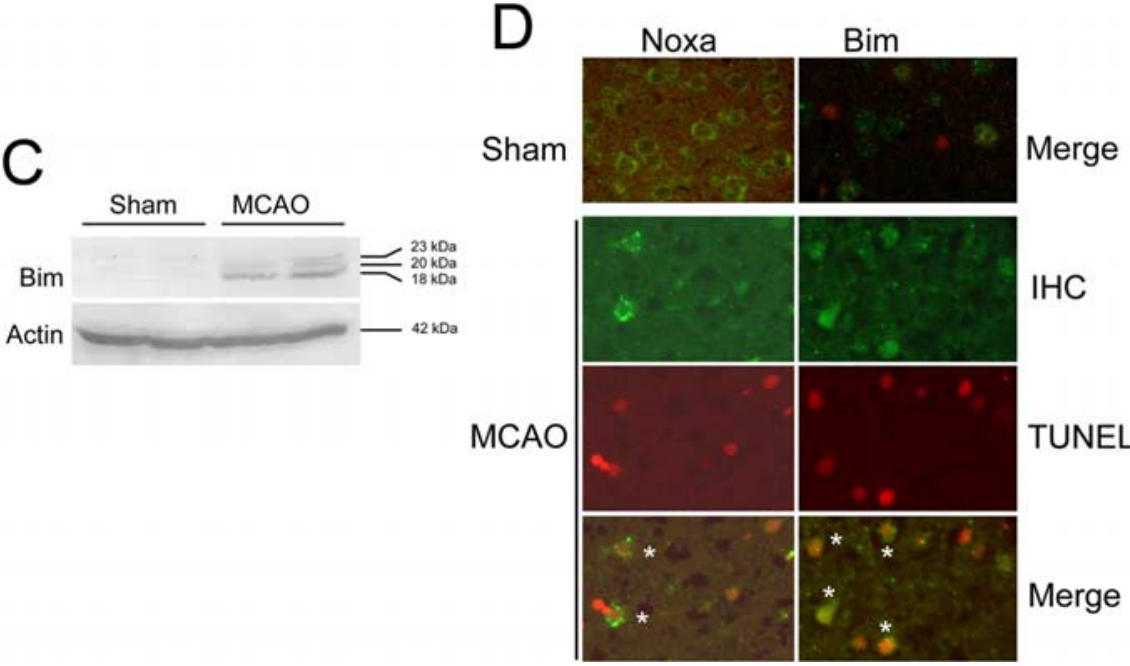

D

Figure 2. Expression of BH3-only genes after MCAO. $\boldsymbol{A}$, mRNA accumulation in the ischemic cortex after $24 \mathrm{~h}$ of MCAO was quantified by real-time RT-PCR. Bottom, Values are means \pm SEM $(n=12)$ and expressed relative to the contralateral nonischemic side. ${ }^{*} p<0.02$; ${ }^{* *} p<0.003$ (two-tailed $t$ test). Gel electrophoresis verified the correct size of amplified PCR products (top). $\boldsymbol{B}$, mRNA accumulation of Bim and Noxa was not different between core and periphery of the infarcted area after $24 \mathrm{~h}$ of MCA0. ns, Not significant. C, Immunoblotting showed upregulation of Bim $24 \mathrm{~h}$ after MCAO. The three bands correspond to BimEL (23 kDa), BimL (20 kDa), and BimS (18 kDa). D, Immunohistochemistry (IHC) demonstrated upregulation of Bim and Noxa after cerebral ischemia. Low levels of Noxa and Bim were detected in the cortex of sham-operated mice (top). Bim or Noxa (green) was expressed by TUNEL-positive cells (red) $24 \mathrm{~h}$ after MCAO (bottom). * , Double-positive cells. fectamine 2000 (Invitrogen), $0.2 \mu \mathrm{g}$ per well of the Noxa or Bim plasmid, and $0.8 \mu \mathrm{g}$ per well of the RcCMV-p65 or pBluescript plasmids as described previously (Potrovita et al., 2004). To normalize the transfection efficiency, $0.02 \mu \mathrm{g}$ per well Renilla luciferase (phRLTK) control plasmid (Promega, Mannheim, Germany) was used. After $52 \mathrm{~h}$, cells were harvested, and firefly and Renilla luciferase were measured using Dual Luciferase Reporter Assay (Promega).

Electrophoretic mobility shift assay. Cos cells on $9 \mathrm{~cm}$ plates were transfected with RcCMVp65 for $24 \mathrm{~h}$. Cell extracts were prepared as described previously (Schreiber et al., 1989). Protein and a double-stranded oligonucleotide from the $\kappa$ B-enhancer (GAT CCA GAG GGG ACT TTC CGA GA) labeled with ${ }^{32} \mathrm{P}$ by a Klenow fill-in reaction were incubated at $4^{\circ} \mathrm{C}$ in the following buffer: $1 \mathrm{~mm}$ EDTA, $0.5 \mu \mathrm{g} / \mu \mathrm{l} \mathrm{BSA}$, $10 \mathrm{~mm}$ Tris- $\mathrm{HCl}, \mathrm{pH} 7.5,50 \mathrm{~mm} \mathrm{NaCl}, 1 \mathrm{~mm}$ DTT, and 5\% glycerol (total volume, $20 \mu \mathrm{l}$ ). For competition, the following double-stranded oligonucleotides were used: $m \kappa \mathrm{B}$, GAT CCA GAC CAT GGT ATC CGA GA; Bim, GAT CGG GGG TGG GGC TTA CCT TCC GGC; mBim, GAT CGG GGG TAG GGC TTA TCT TCC GGC; NохакB2, GAT CGT CTT GGG GGA GCC CCA GAG CCC; and mNoхакB2, GAT CGT CTT GGA AGA GCC CCA GAG CCC. Protein-DNA complexes were resolved on a $6 \%$ nondenaturing polyacrylamide gel at $280 \mathrm{~V}$.

\section{Results}

To find out which subunits of NF- $\kappa$ B are activated in cerebral ischemia, we performed an ELISA-based analysis of DNA binding of the NF- $\kappa \mathrm{B}$ subunits. All five subunits were activated in the ischemic hemisphere, although the relative activation between the core and the periphery of the ischemic area differed between the subunits (Fig. 1A). Similar results were obtained by immunoblotting of the same nuclear extracts (Fig. $1 B$, left). Immunohistochemistry with an antibody that specifically recognizes active RelA (Kaltschmidt et al., 1995) confirmed that RelA is activated in neurofilament-200-positive neurons (Fig. $1 B$, right) (Herrmann et al., 2005).

Previous work has shown that the subunit p50 contributes to ischemic brain damage (Schneider et al., 1999; Nurmi et al., 2004). Because germline deletion of RelA causes embryonic death (Beg et al., 1995), we used a conditional knock-out approach to delete RelA in neurons and glial cells. We deleted RelA in neural cells (RelA ${ }^{\mathrm{CNSKO}}$ ) by crossing mice carrying floxed RelA alleles with transgenic mice expressing the Cre recombinase under control of the nestin promoter (Betz et al., 1996) (Fig. 1C). RelA ${ }^{\text {CNSKO }}$ mice were healthy and viable. The deletion in the Rel$\mathrm{A}^{\mathrm{CNSKO}}$ mice did not affect the expression of the adjacent gene on the $3^{\prime}$ side of RelA, sipa, as evaluated by reverse transcription 
(RT)-PCR ( sipa1 mRNA, $13.8 \pm 3.0$ relative units in control mice vs $14.1 \pm 8.1$ relative units in RelA ${ }^{\mathrm{CNSKO}}$ mice; $\left.n=3-4\right)$. The nestin-Cre transgenic mouse line has been demonstrated to induce a mosaic phenotype in several organs (Betz et al., 1996). Indeed, Southern blot analysis showed that the RelA gene was partially deleted in several tissues of RelA ${ }^{\text {CNSKO }}$ mice (data not shown). However, this partial deletion had no effect on various physiological parameters, which may affect brain damage in MCAO (Table 2). In RelA ${ }^{\mathrm{CNSKO}}$ mice, a marked deletion of the RelA gene was observed in forebrain, cerebellum, and the eye (Fig. 1D). Because the nestin-Cre transgene targets mainly neurons and astrocytes but not endothelial or microglial cells, a complete loss of RelA in brain extracts is not expected. Immunoblots of RelA in extracts of the nonischemic right hemisphere demonstrated a significant reduction of RelA protein levels by $35 \%(p<$ $0.05 ; n=13-15$ ) (Fig. $1 E$ ). In the same extracts, there was a nonsignificant trend toward lower protein concentrations of the NF- $\kappa \mathrm{B}$ subunit p50 (Fig. $1 E$ ), which may be attributable to the regulation of p50 expression by NF- $\kappa \mathrm{B}$ (Ten et al., 1992). The infarct size after $48 \mathrm{~h}$ of MCAO was significantly reduced in Rel$\mathrm{A}^{\mathrm{CNSKO}}$ mice, showing that RelA promotes ischemic damage (Fig. $1 F$, right). To investigate the functional consequences of p52 activation, we used mice with a germline deficiency of the subunit p52 (Paxian et al., 2002). These mice showed no statistically significant difference in infarct volumes compared with wild-type controls (Fig. $1 F$, left). The role of c-Rel was studied in mice harboring a germline deletion of the $c$-Rel gene (Liou et al., 1999). Germline deletion of $c$-Rel had no effect on the infarct volume $48 \mathrm{~h}$ after onset of MCAO either (Fig. $1 \mathrm{~F}$, middle). Because of poor health, RelB-deficient mice were not included in this study (Weih et al., 1995).

To search for genes that may mediate the neurodegenerative function of RelA, we measured the expression of various $\mathrm{BH} 3$ only genes by real-time RT-PCR $24 \mathrm{~h}$ after permanent MCAO in mice. Of nine BH3-only genes, Bid, Noxa, Bik, and Bim were significantly upregulated after MCAO (Fig. 2A). There was no difference between the induction of Bim and Noxa mRNA in the core and periphery of the ischemia (Fig. 2 B). Alternative splicing generates three isoforms of Bim (BimEL, $23 \mathrm{kDa}$; BimL, $20 \mathrm{kDa}$; and BimS, $18 \mathrm{kDa}$ ). Our real-time RT-PCR is specific for BimS, which has the highest apoptotic potency of the isoforms. Immunoblots supported the induction of BimS and demonstrated that the other isoforms were also enhanced by MCAO (Fig. 2C). Moreover, immunohistochemistry confirmed the upregulation of Bim and Noxa $24 \mathrm{~h}$ after permanent MCAO. Bim and Noxa staining was partially colocalized with TUNEL, suggesting that Bim and Noxa are implicated in apoptotic cell death after cerebral ischemia (Fig. 2D).

In cerebral ischemia, apoptotic cell death mainly affects neurons. To approach the question of whether $\mathrm{BH} 3$-only genes are induced in neurons, we exposed primary cortical mouse neurons to camptothecin, a topoisomerase I blocker that models DNA damage in cerebral ischemia. Camptothecin stimulated the expression of Noxa and Bim at 16 and $24 \mathrm{~h}$ of exposure, whereas the expression of Bid and Bik was only enhanced after $24 \mathrm{~h}$ of stimulation (Fig. 3A). A similar picture emerged after exposure of cortical neurons to OGD, an in vitro model of cerebral ischemia. Bim, Noxa, and Bik were significantly induced at the mRNA level by 6 h of OGD (Fig. 3B). However, Bid expression was not stimulated by OGD in cortical neurons. Thus, Bik, Noxa, and Bim are induced by in vivo and in vitro models of cerebral ischemia.

To investigate the effect of RelA on the induction of $\mathrm{BH} 3$-only genes, we measured mRNA levels of the four $\mathrm{BH} 3$-only genes that
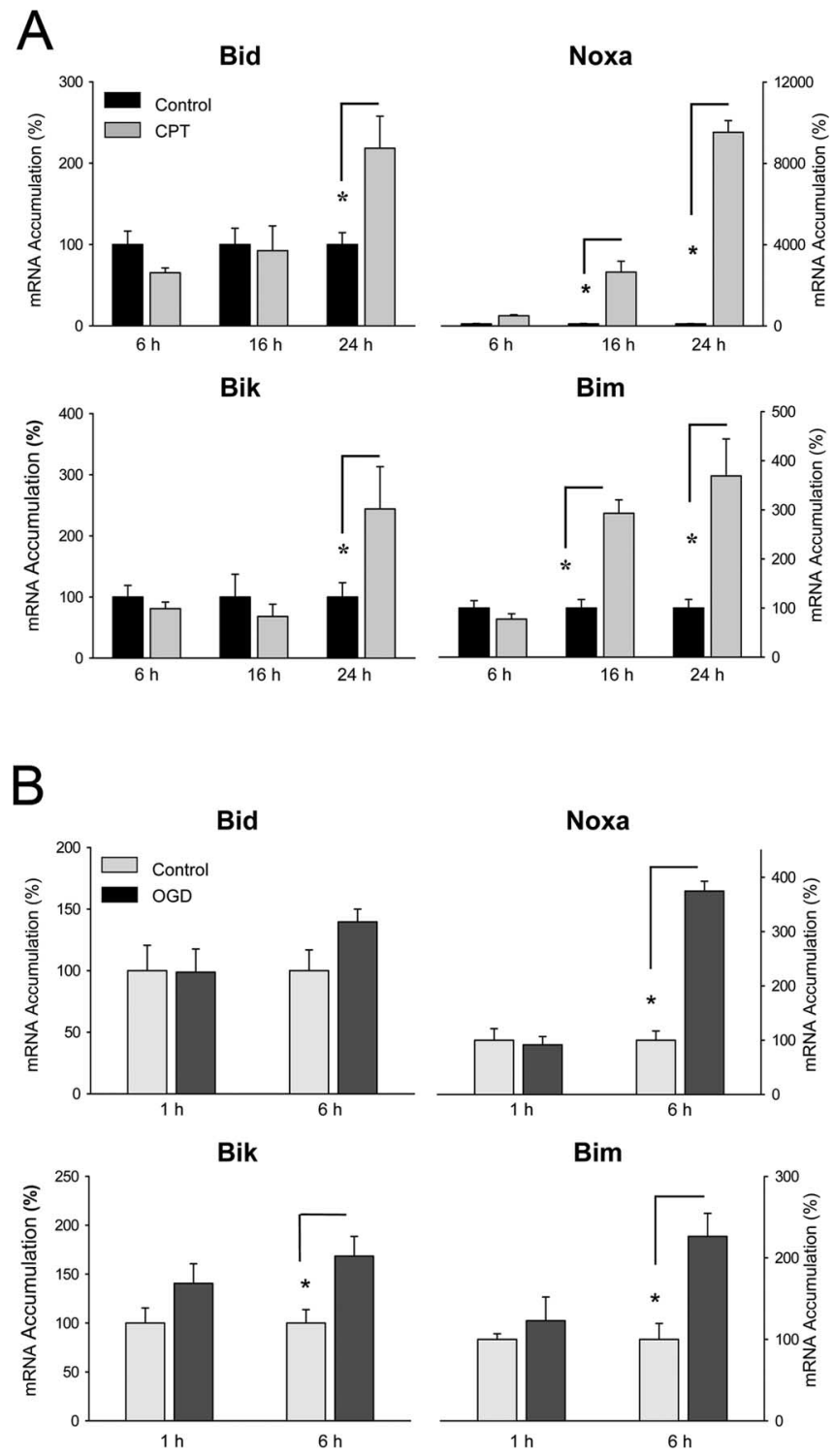

Figure 3. Induction of $\mathrm{BH} 3$-only genes in primary cortical neurons in in vitro models of cerebral ischemia. $\boldsymbol{A}$, Camptothecin (CPT; $10 \mu \mathrm{M}$ ) exposure enhanced mRNA accumulation of Bid, Bik, Noxa, and Bim in a time-dependent manner. Values are means \pm SEM $(n=7-8)$ and expressed relative to the unstimulated control group. ${ }^{*} p<0.006$ [ANOVA; least significant difference (LSD) post hoc]. B, OGD stimulates mRNA accumulation of Bik, Noxa, and Bim in a time-dependent manner. Values are means $\pm \operatorname{SEM}(n=5-6)$ and expressed relative to the group not exposed to OGD. ${ }^{*} p<0.01$ (ANOVA; LSD post hoc).

were found to be upregulated in wild-type mice. The induction of Bim and Noxa in wild-type mice was abolished in RelA ${ }^{\text {CNSKO }}$ mice, whereas the upregulation of Bik persisted in RelA ${ }^{\text {CNSKO }}$ mice (Fig. $4 A$ ). Previous work has shown that NF- $\kappa$ B is activated in cerebral ischemia by the IKK complex. BMS-345541, a specific IKK inhibitor (Burke et al., 2003), protected against ischemic brain damage (Herrmann et al., 2005). IKK activity is reflected by the phosphorylation state of IKK. Intracerebroventricular injection of BMS-345541 reduced IKK phosphorylation $4.5 \mathrm{~h}$ after MCAO in the periphery of the ischemic area, confirming that BMS-345541 is an effective inhibitor of IKK in vivo (Fig. 4 B). To explore the function of IKK in the induction of Bim and Noxa, we injected mice intracerebroventricularly with BMS-345541 or vehicle and measured Bim and Noxa mRNA at three time points after MCAO. Bim and Noxa were first upregulated after $6 \mathrm{~h}$ of 
A
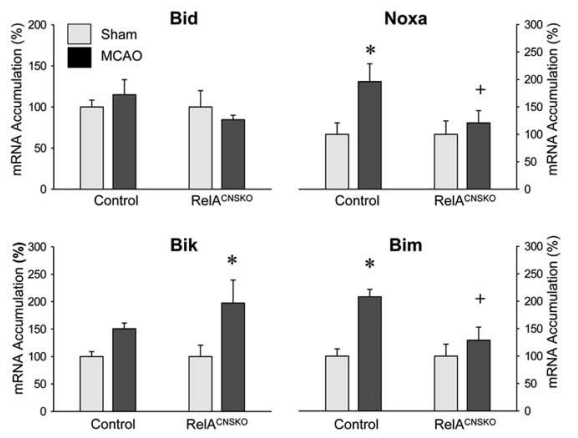

B
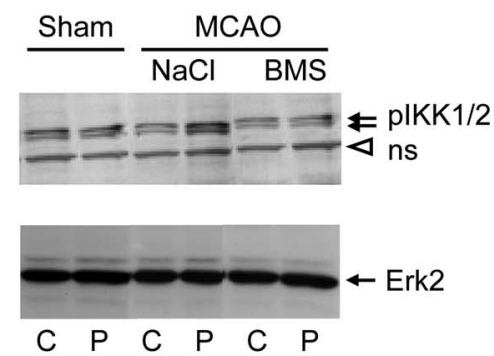

C

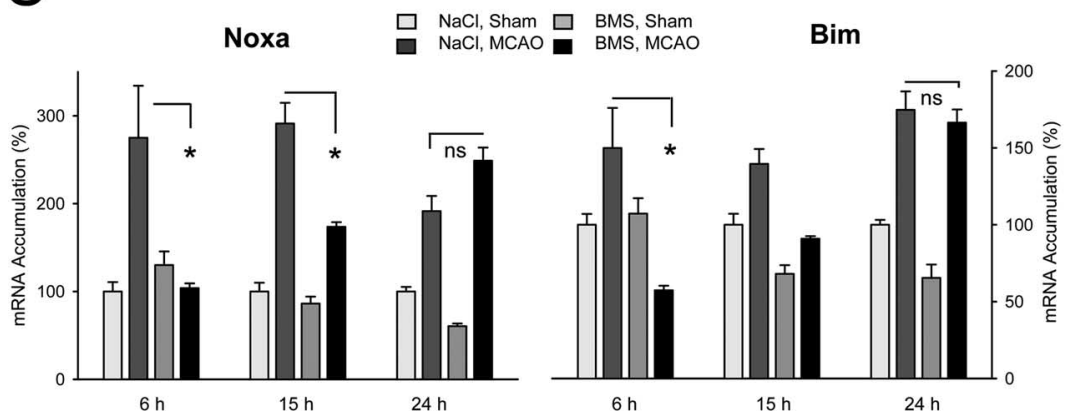

Figure 4. Induction of Bim and Noxa by MCAO depends on the IKK/NF- $\kappa B$ signaling pathway. $A$, In Rel ${ }^{\text {CNSKO }}$ mice, Bim and Noxa mRNA accumulation was not enhanced $24 \mathrm{~h}$ after MCAO ${ }^{*} p<0.004$ compared with sham group. ${ }^{+} p<0.02$ compared with wild-type mice with MCA0. $n=3-4$ [ANOVA; least significant difference (LSD) posthoc]. $B$, Phospho-IKK1/2 in the periphery (P) of the ischemic cortex was decreased in mice injected with $12 \mu \mathrm{g}$ of BMS-345541 intracerebroventricularly as shown by immunoblot. In the core (C) of the ischemia, phospho-IKK1/2 was not affected by MCAO. Mice were analyzed $4.5 \mathrm{~h}$ after permanent MCAO. Erk2 was used as control for protein loading. ns, Nonspecific band. C, The IKK inhibitor BMS-345541 transiently inhibited Bim and Noxa mRNA accumulation after MCA0. BMS-345541 was injected intracerebroventricularly immediately before MCA0. ${ }^{*} p<0.05$ compared with vehicle-treated mice with MCAO (ANOVA; LSD post hoc; $n=4-6$ ). ns, Not significant. Values are means \pm SEM.

elements in the Bim and Noxa promoter region, we performed electrophoretic shift assays. The binding of RelA expressed in Cos cells to a consensus NF- $\kappa$ B binding site was inhibited by wild-type Bim and Noxa sites. The mutations that interfered with RelA function also diminished competition of RelA DNA binding (Fig. 5C). These data support the notion that RelA binds to the promoter of Bim and Noxa and stimulates their transcription.

\section{Discussion}

Several investigators have reported on the activation of NF- $\kappa \mathrm{B}$ in cerebral ischemia (Mattson and Camandola, 2001). Here, we specify this finding, showing that all five subunits are activated. In view of this broad activation of NF- $\kappa$ B subunits, it was interesting to compare their effects on ischemic brain damage. Our data support the concept that NF- $\kappa$ B subunits differ in their functional significance. In our paradigm of focal cerebral ischemia, conditional deletion of RelA in the brain reduced the infarct size, whereas a germline knock-out of the genes for the subunits c-Rel and p52 had no effect. Notably, our data do not exclude an effect of c-Rel and p52 on parameters other than infarct size or a potential compensation by redundant mechanisms. Together with the previous finding that $\mathrm{p}^{-1-}$ mice have smaller infarcts (Schneider et al., 1999; Nurmi et al., 2004), the reduced infarct size in RelA $\mathrm{C}^{\text {}}$ NsKO mice suggests that p50/RelA heterodimers or p50/p50 and RelA/RelA ho-

MCAO; at this time, BMS-345541 inhibited the induction. However, BMS-345541 lost its effect after $24 \mathrm{~h}$ of MCAO (Fig. 4C). These data suggest that Bim and Noxa are target genes of IKK and RelA.

To further evaluate the possibility that NF- $\kappa$ B stimulates gene transcription of Noxa and Bim in neurons after cerebral ischemia, we transfected primary cortical neurons with reporter fusion genes, in which the $5^{\prime}$-flanking sequences of the mouse Bim $(-3600 /+96)$ or the mouse Noxa gene $(-183 /+146)$ direct luciferase expression. Indeed, cotransfection of an expression plasmid for RelA stimulated Bim transcription approximately fourfold (Fig. 5A) and Noxa transcription approximately twofold (Fig. $5 B$ ). A search for putative NF- $\kappa$ B binding sites in the $5^{\prime}$ flanking sequence of the Bim and Noxa genes using the TRANSFAC database found one potential binding site in the promoter of the mouse Bim gene $(-62 /-53)$ and two close to the transcription start site of the Noxa gene $(-49 /-40 ;+87 /+96)$, with the second site being almost palindromic. Mutation of the $\mathrm{NF}-\kappa \mathrm{B}$ binding site in the Bim promoter significantly reduced luciferase expression (Fig. 5A). The residual effect of RelA after mutation of the NF- $\kappa \mathrm{B}$ site suggests that the mutation may not destroy RelA binding completely or there may be other sites in the 5 -flanking sequence. Mutation of the first NF- $\kappa \mathrm{B}$ binding site $(\kappa \mathrm{B} 1)$ in the Noxa promoter had no effect, but mutation of the second binding site $(\kappa \mathrm{B} 2)$ blocked the stimulation by RelA (Fig. $5 B)$. To further test whether RelA binds to the identified response modimers promote ischemic brain damage. A slight reduction of p50 levels in brains of RelA ${ }^{\text {CNSKO }}$ mice (Fig. $1 E$ ) might have contributed to protection in cerebral ischemia. The predominant role of p50 and RelA is in accordance with their abundance in the brain and in other tissues (Hoffmann et al., 2003; Kaltschmidt et al., 2005). In the canonical NF- $\kappa$ B pathway, p50 and RelA activation is triggered by the upstream IKK kinase complex with the subunits IKK1, IKK2, and NEMO (NF- $\kappa$ B essential modulator). Indeed, IKK2 deletion or inhibition was shown to ameliorate ischemic brain damage (Herrmann et al., 2005). Thus, interference with the NF- $\kappa$ B pathway at various levels reveals a deleterious role of NF- $\kappa \mathrm{B}$ in cerebral ischemia, which is in apparent contrast to what has been found in other paradigms. There is ample evidence that NF- $\kappa \mathrm{B}$ inhibits apoptosis in tumor cells, hepatocytes, and many other cell types, including neurons (Pizzi et al., 2002; Fridmacher et al., 2003; Tarabin and Schwaninger, 2004). In stroke models, however, protective effects of NF- $\kappa$ B, which may be mediated by c-Rel (Pizzi et al., 2002), are overrun by the deleterious action of p 50 and RelA. In accordance with this concept, deletion of c-Rel had no effect on infarct size (Fig. $1 F$ ). In contrast, the protective role of NF- $\kappa$ B seems to prevail in short cerebral ischemia, which leads to ischemic preconditioning (Blondeau et al., 2001).

NF- $\kappa$ B promotes cell survival through induction of $\mathrm{Bcl}-2$ and Bcl- $\mathrm{X}_{\mathrm{L}}$ (Lee et al., 1999; Tamatani et al., 1999; Mattson and Ca- 
A
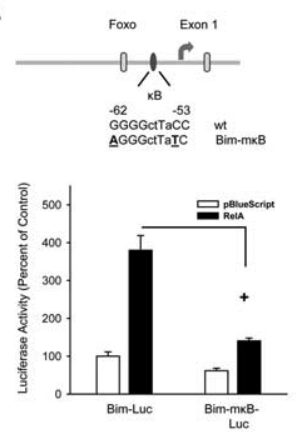

B
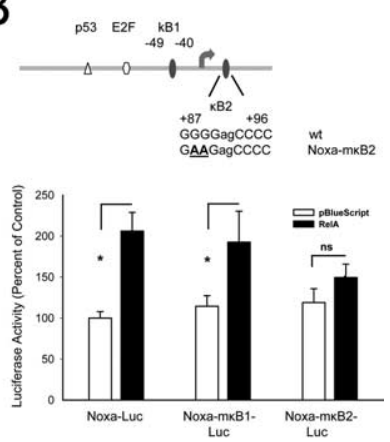

C

NYYCC of NF- $\kappa \mathrm{B}$ exactly, where R represents purine, Y represents pyrimidine, and $\mathrm{N}$ represents any base (Ghosh et al., 1998). The sequence in the Bim promoter (GGGGCTTACC) deviates by a purine in position 8 from the consensus sequence. However, the same variation occurs in the NF- $\kappa$ B motif of the GM-CSF (granulocyte/macrophage colony-stimulating factor) gene, which is a high-affinity binding site (Schreck and Baeuerle, 1990).

An indirect mechanism through which NF- $\kappa \mathrm{B}$ is able to regulate Noxa gene transcription was suggested by Aleyasin et al. (2004). These authors found that, when DNA had been damaged, NF- $\kappa$ B stimulated Noxa and Puma gene transcription through induction of p53 expression. Focal cerebral ischemia only stimulated Noxa but not Puma mRNA accumulation, suggesting an underlying mechanism other than $\mathrm{p} 53$. In addition to the direct induction of Noxa and Bim by the IKK/NF- $\kappa$ B pathway that we propose here, indirect interactions with other signaling cascades known to be involved in Bim expression are possible. IKK has been shown to inhibit the transcription factor FOXO3a (Hu et al., 2004), which stimulates Bim gene transcription (Gilley et al., 2003; Sunters et al., 2003). Likewise, NF- $\kappa$ B inhibits the effect of JNK on gene transcription (De Smaele et al., 2001; Tang et al., 2001; Park et al., 2004). JNK has been shown to control Bim transcription in cerebral ischemia (Kuan et al., 2003; Okuno et al., 2004). Thus, IKK/NF- $\kappa$ B cross talk with FOXO3a or JNK may counteract the induction of Bim transcription caused by the direct stimulation. However, the role of such interactions must be further investigated.

Of note, NF- $\kappa \mathrm{B}$ directs gene transcription of Bcl-2 family members with opposite effects on mitochondrial permeability that are either proapoptotic (Bax, Bim, and Noxa) or antiapoptotic $\left(\mathrm{Bcl}-2\right.$ and $\left.\mathrm{Bcl}-\mathrm{X}_{\mathrm{L}}\right)$. The relative control of these genes may be the switch that determines the enigmatic role of NF- $\kappa \mathrm{B}$ for cell survival. It is possible that the composition of the NF- $\kappa$ B dimer or the activation pattern of other transcription factors determines whether the induction of proapoptotic or antiapoptotic Bcl-2 family members prevails.

\section{References}

Aleyasin H, Cregan SP, Iyirhiaro G, O’Hare MJ, Callaghan SM, Slack RS, Park DS (2004) Nuclear factor- $\kappa \mathrm{B}$ modulates the p53 response in neurons exposed to DNA damage. J Neurosci 24:2963-2973.

Beg A, Sha W, Bronson R, Ghosh S, Baltimore D (1995) Embryonic lethality and liver degeneration in mice lacking the RelA component of NF-kB. Nature 376:167-170.

mandola, 2001). Previous studies reported either an increase or a decrease in Bcl-2 and $\mathrm{Bcl}-\mathrm{X}_{\mathrm{L}}$ expression in cerebral ischemia (Krajewski et al., 1995; Gillardon et al., 1996; Chen et al., 1997). In our stroke model, there was no change in $\mathrm{Bcl}-2$ or $\mathrm{Bcl}-\mathrm{X}_{\mathrm{L}}$ expression (data not shown). However, we found a reproducible upregulation of the proapoptotic $\mathrm{BH} 3$-only genes $\mathrm{Bik}$, Bim, and Noxa by cerebral ischemia. The induction of Bim by cerebral ischemia has been reported previously (Shibata et al., 2002; Gao et al., 2005).

Bim is localized in neurons (Shibata et al., 2002). Indeed, in primary cortical neurons, in vitro OGD induced Bim and Noxa expression. Interestingly, we found that conditional deletion of RelA in neural cells or pharmacological IKK inhibition blocked Bim and Noxa expression but had no effect on Bik induction by cerebral ischemia. RelA seems to directly regulate transcription of the Bim and Noxa gene by binding to the promoter because mutation of the NF- $\kappa \mathrm{B}$ motif near the transcription start site of the Bim and Noxa gene both interfered with the induction by RelA and reduced the binding of RelA to the DNA. The sequence of the NF- $\kappa \mathrm{B}$ site in the $5^{\prime}$ - untranslated region of the Noxa gene (GGGGAGCCCC) matches the consensus binding site GGGRN-

Betz UA, Vosshenrich CA, Rajewsky K, Muller W (1996) Bypass of lethality with mosaic mice generated by Cre-loxP-mediated recombination. Curr Biol 6:1307-1316.

Blondeau N, Widmann C, Lazdunski M, Heurteaux C (2001) Activation of the nuclear factor- $\kappa \mathrm{B}$ is a key event in brain tolerance. $\mathrm{J}$ Neurosci 21:4668-4677.

Bouillet P, Zhang LC, Huang DC, Webb GC, Bottema CD, Shore P, Eyre HJ, Sutherland GR, Adams JM (2001) Gene structure alternative splicing, and chromosomal localization of pro-apoptotic Bcl-2 relative Bim. Mamm Genome 12:163-168.

Burke JR, Pattoli MA, Gregor KR, Brassil PJ, MacMaster JF, McIntyre KW, Yang X, Iotzova VS, Clarke W, Strnad J, Qiu Y, Zusi FC (2003) BMS345541 is a highly selective inhibitor of I kappa B kinase that binds at an allosteric site of the enzyme and blocks NF-kappa B-dependent transcription in mice. J Biol Chem 278:1450-1456.

Cao G, Pei W, Ge H, Liang Q, Luo Y, Sharp FR, Lu A, Ran R, Graham SH, Chen J (2002) In vivo delivery of a Bcl-xL fusion protein containing the TAT protein transduction domain protects against ischemic brain injury and neuronal apoptosis. J Neurosci 22:5423-5431.

Chen J, Graham SH, Nakayama M, Zhu RL, Jin K, Stetler RA, Simon RP (1997) Apoptosis repressor genes $\mathrm{Bcl}-2$ and $\mathrm{Bcl}-\mathrm{x}$-long are expressed in the rat brain following global ischemia. J Cereb Blood Flow Metab 17:2-10.

De Smaele E, Zazzeroni F, Papa S, Nguyen DU, Jin R, Jones J, Cong R, 
Franzoso G (2001) Induction of gadd45beta by NF-kappaB downregulates pro-apoptotic JNK signalling. Nature 414:308-313.

Fridmacher V, Kaltschmidt B, Goudeau B, Ndiaye D, Rossi FM, Pfeiffer J, Kaltschmidt C, Israel A, Memet S (2003) Forebrain-specific neuronal inhibition of nuclear factor- $\kappa \mathrm{B}$ activity leads to loss of neuroprotection. J Neurosci 23:9403-9408.

Gao Y, Signore AP, Yin W, Cao G, Yin XM, Sun F, Luo Y, Graham SH, Chen J (2005) Neuroprotection against focal ischemic brain injury by inhibition of c-Jun N-terminal kinase and attenuation of the mitochondrial apoptosis-signaling pathway. J Cereb Blood Flow Metab 25:694-712.

Ghosh S, May MJ, Kopp E (1998) NF-kB and Rel proteins: evolutionarily conserved mediators of immune responses. Annu Rev Immunol $16: 225-260$.

Gillardon F, Lenz C, Waschke KF, Krajewski S, Reed JC, Zimmermann M, Kuschinsky W (1996) Altered expression of bcl-2, bcl-x, bax, and c-Fos colocalizes with DNA fragmentation and ischemic cell damage following middle cerebral artery occlusion in rats. Brain Res Mol Brain Res 40:254-260.

Gilley J, Coffer PJ, Ham J (2003) FOXO transcription factors directly activate bim gene expression and promote apoptosis in sympathetic neurons. J Cell Biol 162:613-622.

Graham SH, Chen J, Clark RS (2000) Bcl-2 family gene products in cerebral ischemia and traumatic brain injury. J Neurotrauma 17:831-841.

Herrmann O, Tarabin V, Suzuki S, Attigah N, Prinz S, Schneider A, Coserea I, Monyer H, Brombacher F, Schwaninger M (2003) Regulation of body temperature and neuroprotection by endogenous interleukin- 6 in focal cerebral ischemia. J Cereb Blood Flow Metab 23:406-415.

Herrmann O, Baumann B, De Lorenzi R, Muhammad S, Zhang W, Kleesiek J, Malfertheiner M, Köhrmann M, Potrovita I, Maegele I, Beyer C, Burke JR, Hasan MT, Bujard H, Wirth T, Pasparakis M, Schwaninger M (2005) IKK mediates ischemia-induced neuronal cell death. Nat Med 11:1322-1329.

Hershko T, Ginsberg D (2004) Up-regulation of Bcl-2 homology 3 (BH3)only proteins by E2F1 mediates apoptosis. J Biol Chem 279:8627-8634.

Hoffmann A, Leung TH, Baltimore D (2003) Genetic analysis of NF-kap$\mathrm{paB} / \mathrm{Rel}$ transcription factors defines functional specificities. EMBO J 22:5530-5539.

Hu MC, Lee DF, Xia W, Golfman LS, Ou-Yang F, Yang JY, Zou Y, Bao S, Hanada N, Saso H, Kobayashi R, Hung MC (2004) IkappaB kinase promotes tumorigenesis through inhibition of forkhead FOXO3a. Cell 117:225-237.

Kaltschmidt B, Kaltschmidt C, Hofmann TG, Hehner SP, Droge W, Schmitz ML (2000) The pro- or anti-apoptotic function of NF-kappaB is determined by the nature of the apoptotic stimulus. Eur J Biochem 267:3828-3835.

Kaltschmidt B, Heinrich M, Kaltschmidt C (2002) Stimulus-dependent activation of NF-kappaB specifies apoptosis or neuroprotection in cerebellar granule cells. Neuromolecular Med 2:299-309.

Kaltschmidt B, Widera D, Kaltschmidt C (2005) Signaling via NF- $\kappa$ B in the nervous system. Biochim Biophys Acta 1745:287-299.

Kaltschmidt C, Kaltschmidt B, Henkel T, Stockinger H, Baeuerle PA (1995) Selective recognition of the activated form of transcription factor NFkappa B by a monoclonal antibody. Biol Chem Hoppe-Seyler 376:9-16.

Krajewski S, Mai JK, Krajewska M, Sikorska M, Mossakowski MJ, Reed JC (1995) Upregulation of bax protein levels in neurons following cerebral ischemia. J Neurosci 15:6364-6376.

Kuan CY, Whitmarsh AJ, Yang DD, Liao G, Schloemer AJ, Dong C, Bao J, Banasiak KJ, Haddad GG, Flavell RA, Davis RJ, Rakic P (2003) A critical role of neural-specific JNK3 for ischemic apoptosis. Proc Natl Acad Sci USA 100:15184-15189.

Lee HH, Dadgostar H, Cheng Q, Shu J, Cheng G (1999) NF-kappaBmediated up-regulation of Bcl-x and Bfl-1/A1 is required for CD40 survival signaling in B lymphocytes. Proc Natl Acad Sci USA 96:9136-9141.

Li Q, Verma IM (2002) NF-kappaB regulation in the immune system. Nat Rev Immunol 2:725-734.

Liou HC, Jin Z, Tumang J, Andjelic S, Smith KA, Liou ML (1999) c-Rel is crucial for lymphocyte proliferation but dispensable for $\mathrm{T}$ cell effector function. Int Immunol 11:361-371.

Mattson MP, Camandola S (2001) NF-kappaB in neuronal plasticity and neurodegenerative disorders. J Clin Invest 107:247-254

Nurmi A, Lindsberg PJ, Koistinaho M, Zhang W, Juettler E, KarjalainenLindsberg ML, Weih F, Frank N, Schwaninger M, Koistinaho J (2004) Nuclear factor-kappaB contributes to infarction after permanent focal ischemia. Stroke 35:987-991.

Oda E, Ohki R, Murasawa H, Nemoto J, Shibue T, Yamashita T, Tokino T,
Taniguchi T, Tanaka N (2000) Noxa, a BH3-only member of the Bcl-2 family and candidate mediator of p53-induced apoptosis. Science 288:1053-1058.

Okuno S, Saito A, Hayashi T, Chan PH (2004) The c-Jun N-terminal protein kinase signaling pathway mediates Bax activation and subsequent neuronal apoptosis through interaction with Bim after transient focal cerebral ischemia. J Neurosci 24:7879-7887.

Park JM, Brady H, Ruocco MG, Sun H, Williams D, Lee SJ, Kato Jr T, Richards N, Chan K, Mercurio F, Karin M, Wasserman SA (2004) Targeting of TAK1 by the NF-kappa B protein Relish regulates the JNK-mediated immune response in Drosophila. Genes Dev 18:584-594.

Paxian S, Merkle H, Riemann M, Wilda M, Adler G, Hameister H, Liptay S, Pfeffer K, Schmid RM (2002) Abnormal organogenesis of Peyer's patches in mice deficient for NF-kappaB1, NF-kappaB2, and Bcl-3. Gastroenterology 122:1853-1868.

Pizzi M, Goffi F, Boroni F, Benarese M, Perkins SE, Liou HC, Spano P (2002) Opposing roles for NF-kappa B/Rel factors p65 and c-Rel in the modulation of neuron survival elicited by glutamate and interleukin-1beta. J Biol Chem 277:20717-20723.

Pizzi M, Sarnico I, Boroni F, Benarese M, Steimberg N, Mazzoleni G, Dietz GP, Bahr M, Liou HC, Spano PF (2005) NF-kappaB factor c-Rel mediates neuroprotection elicited by mGlu5 receptor agonists against amyloid beta-peptide toxicity. Cell Death Differ 12:761-772.

Potrovita I, Zhang W, Burkly L, Hahm K, Lincecum J, Wang MZ, Maurer MH, Rossner M, Schneider A, Schwaninger M (2004) Tumor necrosis factor-like weak inducer of apoptosis-induced neurodegeneration. J Neurosci 24:8237-8244.

Schneider A, Martin-Villalba A, Weih F, Vogel J, Wirth T, Schwaninger M (1999) NF- $\kappa$ B is activated and promotes cell death in focal cerebral ischemia. Nat Med 5:554-559.

Schreck R, Baeuerle PA (1990) NF-kappa B as inducible transcriptional activator of the granulocyte-macrophage colony-stimulating factor gene. Mol Cell Biol 10:1281-1286.

Schreiber E, Matthias P, Müller MM, Schaffner W (1989) Rapid detection of octamer binding proteins with 'mini-extracts', prepared from small number of cells. Nucleic Acids Res 17:6419.

Shibata M, Hattori H, Sasaki T, Gotoh J, Hamada J, Fukuuchi Y (2002) Temporal profiles of the subcellular localization of Bim, a BH3-only protein, during middle cerebral artery occlusion in mice. J Cereb Blood Flow Metab 22:810-820.

Strasser A (2005) The role of BH3-only proteins in the immune system. Nat Rev Immunol 5:189-200.

Sunters A, Fernandez de Mattos S, Stahl M, Brosens JJ, Zoumpoulidou G, Saunders CA, Coffer PJ, Medema RH, Coombes RC, Lam EW (2003) FoxO3a transcriptional regulation of Bim controls apoptosis in paclitaxel-treated breast cancer cell lines. J Biol Chem 278:49795-49805.

Tamatani M, Che YH, Matsuzaki H, Ogawa S, Okado H, Miyake S, Mizuno T, Tohyama M (1999) Tumor necrosis factor induces Bcl-2 and Bcl-x expression through NFkappaB activation in primary hippocampal neurons. J Biol Chem 274:8531-8538.

Tang G, Minemoto Y, Dibling B, Purcell NH, Li Z, Karin M, Lin A (2001) Inhibition of JNK activation through NF-kappaB target genes. Nature 414:313-317.

Tarabin V, Schwaninger M (2004) The role of NF-kappaB in 6-hydroxydopamine- and TNFalpha-induced apoptosis of PC12 cells. Naunyn Schmiedebergs Arch Pharmacol 369:563-569.

Ten RM, Paya CV, Israel N, Le Bail O, Mattei MG, Virelizier JL, Kourilsky P, Israel A (1992) The characterization of the promoter of the gene encoding the p50 subunit of NF-kappa B indicates that it participates in its own regulation. EMBO J 11:195-203.

Weih F, Carrasco D, Durham SK, Barton DS, Rizzo CA, Ryseck R-P, Lira SA, Bravo R (1995) Multiorgan inflammation and hematopoietic abnormalities in mice with a targeted disruption of RelB, a member of the NF-kB/Rel family. Cell 80:331-340.

Xu L, Zhan Y, Wang Y, Feuerstein GZ, Wang X (2002) Recombinant adenoviral expression of dominant negative IkappaBalpha protects brain from cerebral ischemic injury. Biochem Biophys Res Commun 299:14-17.

Yu J, Zhang L (2003) No PUMA, no death: implications for p53-dependent apoptosis. Cancer Cell 4:248-249.

Zhang W, Potrovita I, Tarabin V, Herrmann O, Beer V, Weih F, Schneider A, Schwaninger M (2005) Neuronal activation of NF- $\kappa$ B contributes to cell death in cerebral ischemia. J Cereb Blood Flow Metab 25:30-40. 